\title{
Physiological response of invasive mussel Limnoperna fortunei (Dunker, 1857) (Bivalvia: Mytilidae) submitted to transport and experimental conditions
}

\author{
N. I. S. Cordeiro ${ }^{a, b}$, J. T. M. Andrade ${ }^{a, c}$, L. C. Montresord, D. M. R. Luz ${ }^{a, b}$, J. M. Araújo ${ }^{a}$, \\ C. B. Martinez ${ }^{b}$, J. Pinheiro ${ }^{e}$ and T. H. D. A. Vidigal ${ }^{a, b *}$
}

\begin{abstract}
${ }^{a}$ Laboratório de Malacologia e Sistemática Molecular, Departamento de Zoologia, Instituto de Ciências Biológicas, Universidade Federal de Minas Gerais - UFMG, Campus Pampulha, Avenida Antônio Carlos, 6627, CEP 31270-901, Belo Horizonte, MG, Brasil

'Laboratório de Estudos de Limnoperna fortunei - LELf, Centro de Pesquisas Hidráulicas e Recursos Hídricos, Universidade Federal de Minas Gerais - UFMG, Campus Pampulha, Avenida Antônio Carlos, 6627, CEP 31270-901, Belo Horizonte, MG, Brasil
\end{abstract}
cPrograma de Pós-graduação em Zoologia, Departamento de Zoologia, Universidade Federal de Minas Gerais - UFMG, Campus Pampulha, Avenida Antônio Carlos, 6627, CEP 31270-901, Belo Horizonte, MG, Brasil
dLaboratório de Malacologia, Instituto Oswaldo Cruz, Fundação Oswaldo Cruz - FIOCRUZ, Avenida Brasil, 4365, Manguinhos, CEP 21040-900, Rio de Janeiro, RJ, Brasil
'Laboratório de Biofísica, Departamento de Ciências Fisiológicas, Instituto de Biologia, Universidade Federal Rural do Rio de Janeiro - UFRRJ, BR 465, Km 7, CEP 23897-000, Seropédica, RJ, Brasil
*e-mail: teofania.vidigal@gmail.com

Received: September 30, 2015 - Accepted: November 23, 2015 - Distributed: February 28, 2017

(With 2 figures)

\begin{abstract}
Successful animal rearing under laboratory conditions for commercial processes or laboratory experiments is a complex chain that includes several stressors (e.g., sampling and transport) and incurs, as a consequence, the reduction of natural animal conditions, economic losses and inconsistent and unreliable biological results. Since the invasion of the bivalve Limnoperna fortunei (Dunker, 1857) in South America, several studies have been performed to help control and manage this fouling pest in industrial plants that use raw water. Relatively little attention has been given to the laboratory rearing procedure of $L$. fortunei, its condition when exposed to a stressor or its acclimation into laboratory conditions. Considering this issue, the aims of this study are to (i) investigate L. fortunei physiological responses when submitted to the depuration process and subsequent air transport (without water/dry condition) at two temperatures, based on glycogen concentrations, and (ii) monitor the glycogen concentrations in different groups when maintained for 28 days under laboratory conditions. Based on the obtained results, depuration did not affect either of the groups when they were submitted to approximately eight hours of transport. The variation in glycogen concentration among the specimens that were obtained from the field under depurated and non-depurated conditions was significant only in the first week of laboratory growth for the non-depurated group and in the second week for the depurated group. In addition, the tested temperature did not affect either of the groups that were submitted to transport. The glycogen concentrations were similar to those of the specimens that were obtained from the field in third week, which suggests that the specimens acclimated to laboratory conditions during this period of time. Thus, the results indicate that the air transport and acclimation time can be successfully incorporated into experimental studies of L. fortunei. Finally, the tolerance of $L$. fortunei specimens to the stressor tested herein can help us understand the invasive capacity of this mussel during the establishment process.
\end{abstract}

Keywords: bioinvasion, glycogen, golden mussel, physiology.

\section{Resposta fisiológica do mexilhão invasor Limnoperna fortunei (Dunker, 1857) (Bilvalvia: Mytilidae) submetido ao transporte e condições experimentais}

\section{Resumo}

A criação bem sucedida de animais em condições de laboratório para processos comerciais ou experimentais é uma cadeia complexa que inclui vários fatores de estresse (ex. coleta e transporte) que tem como consequência a redução das condições naturais do animal, prejuízos econômicos e resultados biológicos inconsistentes. Desde a invasão do bivalve Limnoperna fortunei (Dunker, 1857) na América do Sul, vários estudos têm sido realizados para ajudar no 
controle e gestão dessa praga em plantas industriais que utilizam água. Relativamente pouca atenção tem sido dada ao processo de criação de $L$. fortunei em laboratório, sua condição quando exposta ao estresse e sua aclimatação a condições de laboratório. Considerando estes aspectos, os objetivos deste estudo foram: (i) investigar as respostas fisiológicas de L. fortunei submetidos ao processo de depuração e subsequente transporte (sem água/condição seca) em duas temperaturas, analisando as diferentes concentrações de glicogênio e (ii) monitorar as concentrações de glicogênio nos diferentes grupos, quando mantidos por 28 dias em condições de laboratório. Com base nos resultados obtidos, a depuração não afetou nenhum grupo quando eles foram submetidos a oito horas de transporte. A variação da concentração de glicogênio entre os espécimes do campo quando depurados e não depurados, foi significativa apenas em relação à primeira semana em laboratório para o grupo não depurado e à segunda semana para o grupo depurado. Além disto, a temperatura testada não afetou os grupos submetidos ao transporte. As concentrações de glicogénio foram semelhantes as dos espécimes do campo a partir da terceira semana, o que sugere que os espécimes estão aclimatados às condições de laboratoriais neste período de tempo. Assim, os resultados indicam que o transporte ao ar e o tempo de aclimatação podem ser incorporados com sucesso aos estudos experimentais com L. fortunei. Finalmente, o conhecimento sobre a tolerância de $L$. fortune $i$ ao estresse pode ajudar a entender a capacidade invasiva deste durante o processo de estabelecimento.

Palavras-chaves: bioinvasão, glicogênio, mexilhão dourado, fisiologia.

\section{Introduction}

Limnoperna fortunei (Dunker, 1857) (Bivalvia: Mytilidae), or golden mussel, is a freshwater bivalve from Asia that was accidently introduced into South America in the 1990s and rapidly spread thought hydrographic basins, causing severe damage to aquatic ecosystems and to raw water-using industries, potable water treatment plants, and electric power plants (Darrigran and Damborenea, 2011). The success of $L$. fortunei as invader is related to its high adaptability and tolerance to environmental changes (Darrigran et al., 2011; Uliano-Silva et al., 2014). In Brazil, golden mussel invasion is considered one of the most substantial threats and has produced a significant impact on Brazilian watersheds and on the hydroelectric sector, both of which are of significant concern to this country (Rolla and Mota, 2010; Mansur et al., 2012). The golden mussel is established in the south, southeast and central-west regions of Brazil, with prospects to expand its distribution to other Brazilian areas, such as the Amazon basin (Oliveira et al., 2010a; Santos et al., 2012). Therefore, a high priority has been given to the development of reliable, cost-effective, and environmentally acceptable means of $L$. fortunei macrofouling control. Golden mussel macrofouling is characterized by uncontrolled growth and rapid incrustation into hard substrates, on which the organisms set and grow in pipes and the waterway, consequently blocking the water flow and affecting the cooling systems in power plants (Darrigran and Damborenea, 2011). Currently, the main control strategies for golden mussel are based on chemical molluscicides; however, there are few studies on the efficacy of chemicals for macrofouling control (Montresor et al., 2013). In addition, relatively little attention has been given to laboratory rearing proceeds of $L$. fortunei, which ensures the condition and quality of the animals when performing reliable laboratory experiments using chemical compounds. A literature review identifies a lack of standardization in the procedures that are used in experimental studies of L. fortunei, such as sampling, transport, rearing, monitoring of the animal's health, acclimation time to the laboratory, size range of the tested animals, monitored physico-chemical parameters, food availability during the experiments, and criteria for the selection of suitable specimens to be tested for each bioassay (Cataldo et al., 2003; Pereyra et al., 2011, 2012; Di Fiori et al., 2012; Mansur et al., 2012; Calazans et al., 2013; Montresor et al., 2013; Sylvester et al., 2013). In fact, differences between the tested procedures in experimental studies may account for some of the discrepancy observed in the literature results (Rolla and Mota, 2010; Montresor et al., 2013). Animal rearing under laboratory conditions for commercial processes and/or laboratory experiments assumes that the specimens are in good health conditions even after being subjected to stressors (e.g., sampling, handling, abrupt temperature changes and transport) (Gatenby et al., 1998; Patterson et al., 1999; Lee et al., 2008). Thus, the sampling, handling, transport and acclimation are considered crucial steps for successful laboratory maintenance (Englund and Pynnonen, 1996; Anacleto et al., 2013). The specimens exposure to stressors strongly decreases animal quality and can cause severe changes in its metabolism and contribute to mortalities (Patterson et al., 1999; Lee et al., 2008; Anacleto et al., 2013). Low temperatures influence the animal's ability to regulate the consumption of oxygen under hypoxic conditions (e.g., the transport of freshwater mussels exposed to air - without water) and increase the animal's tolerance to low oxygen concentrations (Chen et al., 2001). According to Chase and McMahon (1995), the bivalve Dreissena polymorpha (Pallas, 1771) (known as zebra mussel) appears to be extremely tolerant of starvation (stressor) but showed a greater survival rate when held at $15{ }^{\circ} \mathrm{C}$ than it did when maintained in $25{ }^{\circ} \mathrm{C}$. In fact, a reduction of metabolic activity under low temperature has been observed in other freshwater bivalves (unionid and dreissenid) to reduce their energy consumption when affected by several stressors (Chase and McMahon, 1995; Gatenby et al., 1998). Further, in addition to the use of low temperatures during transport, the specimens can be previously submitted to a depuration 
process that contributes to animal quality and increases the survival rate of bivalves (Richards, 1988; Lee et al., 2008; Anacleto et al., 2013). The depuration process consists of maintaining live organisms (e.g., mussels) in a tank with clean water with constant temperature and aeration and without any feed for 48 hours. During this treatment, the mussels expel potential contaminants through the gill activity and digestive tract. These procedures are considered important for animal quality and acclimation (Richards, 1988; Lee et al., 2008; Anacleto et al., 2013). Thus, acclimation is a set of adaptations under laboratory conditions, and it is important to ensure the conditions and animal quality for performing reliable laboratory experiments (Brasil, 1988; Resgalla Junior et al., 2008; Maroñas and Damborenea, 2009). The acclimation time to L. fortunei, as reported in the literature, ranges from 0 to 20 days (Maroñas and Damborenea, 2009; Oliveira et al., 2010b; Di Fiori et al., 2012; Calazans et al., 2013; Montresor et al., 2013). In fact, in some experiments, the acclimation time is not reported (e.g., Montalto and Drago, 2003; Pestana et al., 2009; Oliveira et al., 2010a). Moreover, to perform reliable laboratory experiments, the choice of specimens for use in each experimental test is important. Thus, based on previous studies (e.g., Pereyra et al., 2011; Di Fiori et al., 2012; Montresor et al., 2013), the selection of golden mussel specimens for bioassays is based on visual inspection, in that specimens were excluded from testing when they did not attach to containers or did not present an extended siphon. However, simple visual inspection of the open shells cannot provide sufficient information about the golden mussel health because, according to Montresor et al. (2013), golden mussel specimens also presented gapping shells when exposed to noxious levels of ammonia. Thus, visual inspection may not be the only valuable method for determining animal health in bioassays.

The physiological effects of transport to the laboratory and acclimation in aquaria are relatively unknown in freshwater bivalves (Gatenby et al., 1998; Chen et al., 2001; Yusufzai et al., 2010), including for the invasive pest L. fortunei. The use of the metabolic reserve, reduction or depletion of glycogen concentrations and how it is used varies between bivalves and is often associated with nutritional conditions (starvation or food availability), the stage of development, sexual maturity (Hummel et al., 1989; Kang et al., 2000; Albentosa et al., 2007; Dridi et al., 2007; Anacleto et al., 2013) and chronic or acute physical or chemical stresses (Nandurkar and Zambare, 2012). According to Patterson et al. (1999), glycogen is the primary energy store in bivalves and is a good physiological parameter of bivalve health status or body condition. Glycogen has been used in different studies, including monitoring its concentration throughout the life cycle of bivalves in the field, during controlled feeding and starvation under laboratory conditions, during relocation, after transport (air and water transport), and under chemical or physical stress (Thompson et al., 1978; Hummel et al., 1989; Patterson et al., 1999; Chen et al., 2001; Newton et al., 2001,
Almeida et al., 2007; Patrick et al., 2006; Yusufzai et al., 2010; Anacleto et al., 2013).

In addition to these issues, others must be considered: (i) the successful rearing of healthy bivalves under laboratory conditions is influenced by many stressors (such as collection, transport and maintenance procedures); (ii) the physiological effects of transport and the determination of acclimation time under laboratory conditions is not well known for freshwater bivalves, including the golden mussel; (iii) the acclimation of animals (e.g., bivalves and fishes) under laboratory conditions for experimental testing is important; and (iv) there is a high demand for studies with bioassays using the golden mussel. Thus, the aims of this study are to (i) investigate the physiological responses (glycogen concentrations) of $L$. fortunei specimens that are submitted to depuration and subsequent transport in air (without water) at two temperatures (approximately $15^{\circ} \mathrm{C}$ and $25^{\circ} \mathrm{C}$ ); (ii) monitor the glycogen concentrations in different groups that were maintained for 28 days under laboratory conditions; and (iii) provide suggestions for improving the sampling, transport and handling of the golden mussel under laboratory conditions. The compiled data of this study provide insights that improve our knowledge about laboratory rearing and bioassays and contribute to control strategies of L. fortunei within and between Brazilian hydrographic basins.

\section{Material and Methods}

\subsection{Sampling and processing of specimens}

Limnoperna fortunei specimens were manually and carefully sampled, avoiding animal injury, at Refúgio Bela Vista of Itaipu' hydroelectric power plant (Paraná River), Foz do Iguaçu, PR, Brazil, (25²6'48.9'S; $\left.54^{\circ} 32^{\prime} 58.1^{\prime \prime} \mathrm{W}\right)$. The specimens were washed using local water (at $25.01^{\circ} \mathrm{C} \pm 1.67^{\circ} \mathrm{C}$ ) to remove organic materials. Subsequently, the washed specimens were submitted to two procedures: (i) the soft tissue of the mussels was removed, and the glycogen concentration was quantified (see the section Glycogen concentration); and (ii) the mussels were submitted to depuration as described by Anacleto et al. (2013). The experimental procedures are summarized in Figure 1.

\subsection{Field procedures: depuration process and transport of specimens}

The depuration process began immediately after the sampling and cleaning of the mussels and was carried out in 200-L aquaria containing dechlorinated tap water with a $6.90 \pm 0.06 \mathrm{pH}, 25.01{ }^{\circ} \mathrm{C} \pm 1.67{ }^{\circ} \mathrm{C}$ temperature, $75.3 \pm 4.81 \%$ oxygen saturation, of $6.06 \pm 0.53 \mathrm{mg} / \mathrm{L}$ dissolved oxygen and constant aeration. The physicochemical parameters in the aquaria were monitored daily using a multiparameter probe (U-50 series Horiba) for 48 hours, during which no food was provided. The sampled specimens that were submitted to each procedure as described in Figure 1 were transported in thermal insulated boxes (transport box - $24 \mathrm{~L}$ ) to the laboratory (an approximately eight-hour 


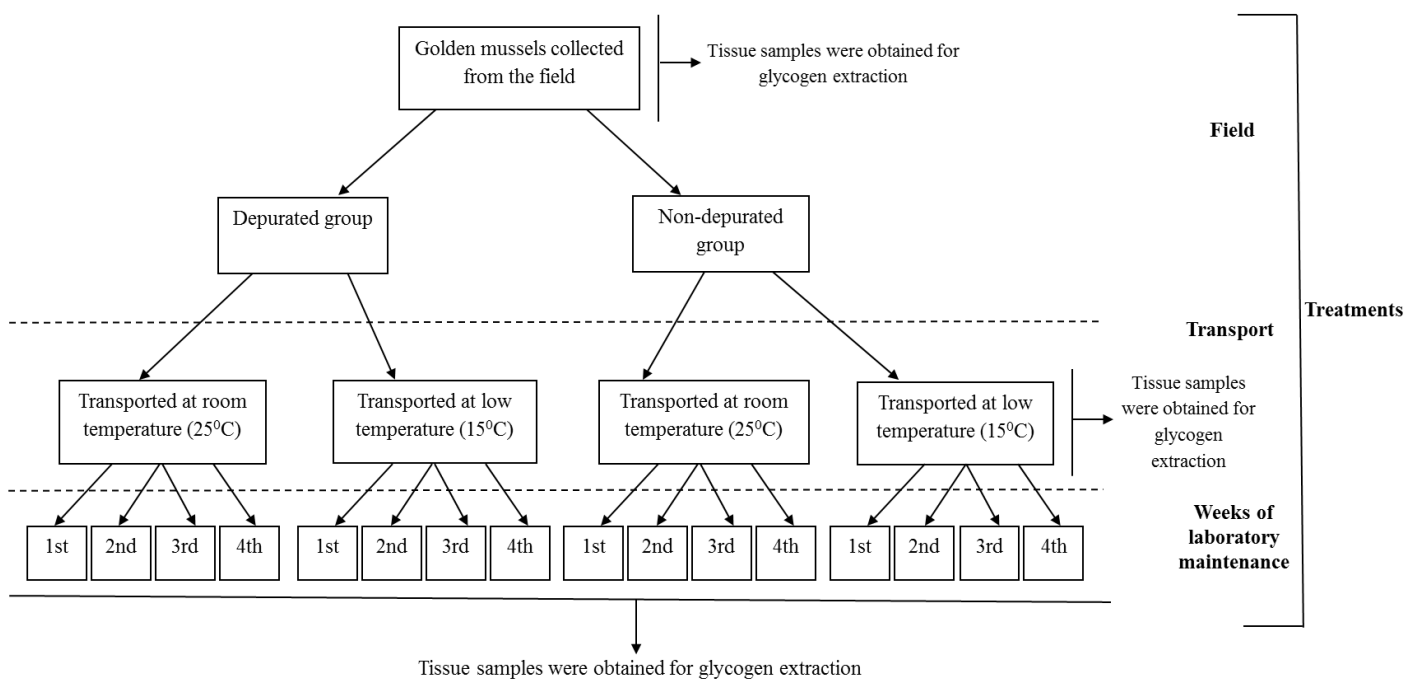

Figure 1. Schematic representation of the experimental design.

transport). Each transport box was previously prepared at two experimental temperatures, approximately $25^{\circ} \mathrm{C}$ (room temperature) and $15^{\circ} \mathrm{C}$, for both the non-depurated and depurated groups. The $15^{\circ} \mathrm{C}$ temperature inside the transport box was reached and maintained by using gel ice packs during transport. Thermometers were used to monitor the temperature levels inside each box. The depurated mussels that were kept at $25^{\circ} \mathrm{C}$ in aquaria (and then transported at $15^{\circ} \mathrm{C}$ in the transport box) were previously submitted to a temperature decrease by adding ice until the temperature reached $15{ }^{\circ} \mathrm{C}$. The temperature was slowly lowered at $1.7^{\circ} \mathrm{C}$ per minute to avoid the thermal shock of the mussels. The depurated and non-depurated specimens were separately packed in plastic bags holding $3 \mathrm{~kg}$ of mussels without water (air transport); subsequently, each bag was filled with $\mathrm{O}_{2}$ using an air compressor, closed and kept in a transport box at distinct temperatures as described below. Because mussels are sensitive to physical damage, the animals were carefully handled to minimize injuries and mortalities. Thus, a soft cloth was wrapped around the gel ice packs to avoid direct contact with the mussels and mechanical shock during transport.

\subsection{Experimental procedures in the laboratory}

The golden mussel specimens were transported to Laboratório de Estudos de Limnoperna fortunei - LELf at Centro de Pesquisas Hidráulicas e Recursos Hídricos (CPH) of Universidade Federal de Minas Gerais (UFMG), Belo Horizonte, Minas Gerais state, Brazil (1952’29.61'S; $\left.43^{\circ} 58^{\prime} 03.41^{\prime \prime} \mathrm{W}\right)$. After arriving at LELf, the boxes were opened, the temperature was measured, and the individuals were transferred to aquaria containing $40 \mathrm{~L}$ of dechlorinated tap water after the temperature difference between the box and the water of the aquarium became less than 2 degrees to prevent the thermal shock of the mussels. The mussel density for the depurated and non-depurated groups was 500 grams (17 individuals per liter) to maintain a compatible density with the total volume of the aquaria during the experimental tests. Then, both groups were maintained in their respective aquarium for 28 days (Figure 1) with constant aeration and a photoperiod cycle of 12:12 h of light:dark, but no food was provided during the first five days. Later, all of the animals were daily feed, three hours before water renovation $(50 \%$ or $100 \%$ daily water renovation), with live algae Scenedesmus Meyen, 1829 (Chlorophyceae: Scenedesmaceae) and Ankistrodesmus Corda, 1838 (Chlorophyceae: Selenastraceae) that were cultivated in the laboratory $\left(0.5 \times 10^{5} \mathrm{cell} / \mathrm{s} / \mathrm{ml}\right)$. The cleaning procedure was carried out every two days before water renovation; organic residues and feces were removed with tap water and a thin paint brush. During the maintenance of the aquarium, the animals were not removed from the aquarium and were not touched to reduce stress. The physicochemical parameters, including the temperature, $\mathrm{pH}$, dissolved oxygen and total ammonia were monitored daily using a pH meter (HI 3221; HI 1131B; Hanna), an optical oximeter (ProODO; YSI), and an ammonia-selective electrode (HI 4101; Hanna). The tap water was dechlorinated with sodium thiosulfate and used in each aquarium to maintain the mussels in the laboratory. The aquaria were maintained under the following conditions: $20.03 \pm 2.98{ }^{\circ} \mathrm{C}$ temperature, $7.7 \pm 0.39 \mathrm{pH}$, $7.63 \pm 0.67 \mathrm{mg} / \mathrm{L}$ dissolved oxygen and $\leq 0.6 \mathrm{mg} / \mathrm{L}$ total ammonia-N.

\subsection{Glycogen quantification}

Glycogen was extracted from the mussel tissue according to Pinheiro and Gomes (1994) and measured according to Sumner (1944) and was expressed as milligrams of glucose per of gram tissue, wet weight (mg glucose / g tissue). The mussel soft tissue was removed from the shells for each 
group; then, the fresh tissues were weighed, divided into three tissue samples of one gram each, and maintained at $-20^{\circ} \mathrm{C}$ until use. The glycogen analysis was performed on sampled specimens from the depurated and non-depurated groups, as shown in Figure 1.

\subsection{Statistical analysis}

To determine whether there was a significant difference in the glycogen concentrations between the depurated and non-depurated groups in the field that were transported or maintained under laboratory conditions for 28 days (first to fourth week) a one-way Variance Analysis (ANOVA) was performed. Comparisons were made a posteriori using a $95 \%$ confidence interval; thus, in those treatments that no overlap between the confidence interval, they were considered significantly different. To check the differences in glycogen concentrations and the interaction between the depurated condition and temperature at different treatments (Figure 1), a factorial Variance Analysis (factorial ANOVA) (Zar, 2009) was performed. All of the statistical analyses were performed using the STATISTICA 8.0 software (StatSoft Inc., 2007).

\section{Results}

The glycogen content after the first week of maintenance of $L$. fortunei specimens under laboratory conditions was significantly higher $(0.34 \pm 0.79 \mathrm{mg}$ glucose / g tissue $)$ than in depurated and non-depurated field animals $(0.15 \pm 0.07 \mathrm{mg}$ of glucose / $\mathrm{g}$ of tissue $)$ and those that were maintained for four weeks in the laboratory $(0.09 \pm 0.06 \mathrm{mg}$ glucose / $\mathrm{g}$ tissue). Based on our results, there was significant difference among treatments of non-depurated animals (ANOVA: $\mathrm{F}_{5,35}=3.69, \mathrm{p}=0.008$ ) (Figure 2, Table 1). However, the glycogen concentrations among non-depurated animals decreased after the first week, and in the fourth week, reached concentrations at levels similar to those obtained in animals from the field $(0.42 \pm 0.11 \mathrm{mg}$ glucose $/ \mathrm{g}$ tissue). There were also significant differences among treatments in the depurated animals (ANOVA: $\mathrm{F}_{5,36}=6.69, \mathrm{p}<0.001$ ). In this group, the glycogen concentrations was significantly higher in the second week in the laboratory $(0.63 \pm 0.41 \mathrm{mg}$ glucose / $\mathrm{g}$ tissue) compared to the results obtained with animals from the field $(0.15 \pm 0.07 \mathrm{mg}$ of glucose $/ \mathrm{g}$ tissue $)$, after the third $(0.12 \pm 0.11 \mathrm{mg}$ of glucose / $\mathrm{g}$ tissue $)$ and fourth $(0.12 \pm 0.08 \mathrm{mg}$ of glucose / $\mathrm{g}$ of tissue) weeks (Figure 2, Table 1).

In addition, no significant difference in glycogen concentrations was found in samples that were obtained from the field or submitted to transport (depurated and non-depurated). Furthermore, regardless of the group (depurated or non-depurated), after three weeks in the laboratory, the glycogen concentrations of the golden mussels became similar to those observed in animals from the field. Based on ANOVA $\left(F_{1,57}=0.71, p=0.40\right)$, no significant influence of temperature on the glycogen concentrations was observed for either the depurated or non-depurated group. In other words, when the effects of

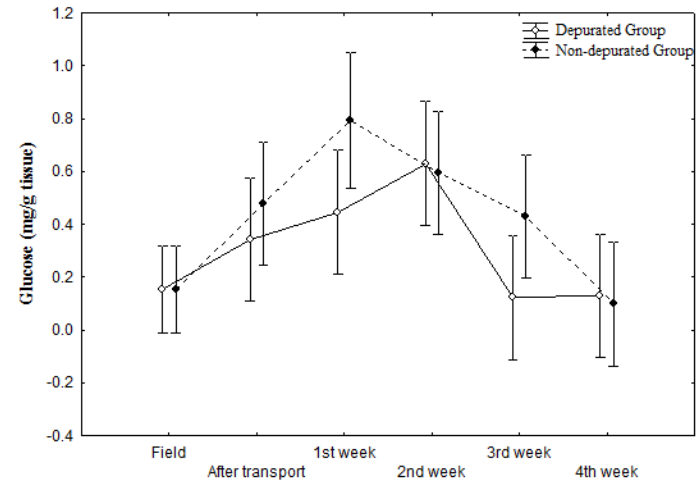

Figure 2. Glycogen content, average values (milligrams of glucose/gram of tissue, wet weight) of L. fortunei with the $95 \%$ confidence interval for the groups: depurated and no-depurated samples obtained from the field and maintained under laboratory conditions over four weeks (28 days).

Table 1. Mean values of concentration of glycogen* ( \pm standard deviation) of Limnoperna fortunei for depurated and non-depurated groups by the analyzed treatments (field, after transport, 1st, 2nd, 3rd and 4th week laboratory maintenance).

\begin{tabular}{ccc}
\hline \multirow{2}{*}{ Treatments } & \multicolumn{2}{c}{ Groups } \\
\cline { 2 - 3 } & Depurated & Non-depurated \\
\hline Field & $0.15 \pm 0.07$ & $0.15 \pm 0.07$ \\
After transport & $0.34 \pm 0.16$ & $0.47 \pm 0.23$ \\
1st week & $0.44 \pm 0.26$ & $0.79 \pm 0.34$ \\
2nd week & $0.63 \pm 0.41$ & $0.59 \pm 0.83$ \\
3rd week & $0.12 \pm 0.11$ & $0.42 \pm 0.11$ \\
4th week & $0.12 \pm 0.08$ & $0.09 \pm 0.06$ \\
\hline
\end{tabular}

*expressed as milligrams of glucose per of gram tissue.

the interaction between the depurated and non-depurated processes were analyzed with the transport temperature of L. fortunei (factorial ANOVA: $\mathrm{F}_{1,55}=0.21, \mathrm{p}=0.64$ ), no significant difference in glycogen concentration was observed.

\section{Discussion}

Variations in glycogen concentrations among specimens of $L$. fortunei obtained from the field and the depurated and non-depurated groups were observed only during the first week for the non-depurated group and the second week for the depurated group. These observations were also detected by Widdows and Bayne (1971), who observed an increase in circulating glucose in Mytilus edulis Linnaeus, 1758 (Bivalvia: Mytilidae) during the second week of acclimation under laboratory conditions. This increase is related to the stress caused by transport (Pekkarinen and Suoranta, 1995) and to acclimation at different temperatures under laboratory conditions (Widdows and Bayne, 1971). However, the increased glycogen concentration did not last 
throughout the analyzed period (28 days); indeed, after three weeks, the glycogen concentration was similar to that obtained from animals of the field, which indicated that the specimens had already acclimatized. The increased glycogen content lasted for a short period of time, which indicated that $L$. fortunei specimens suffered little stress during sampling, transport and acclimation (stressors), as suggested by Chen et al. (2001). The reduction and maintenance of similar glycogen concentrations of those observed in animals that were obtained from the field are considered indicative of a rapid recovery of stress and consequent adaptation to laboratory conditions by the metabolism regulation (Widdows and Bayne, 1971).

Herein, L. fortunei specimens acclimatized within three weeks under laboratory conditions. Indeed, bivalves are often subjected to wide temperature variation when submitted to transport and relocation; thus, in the glycogen content analysis, the temperature fluctuation negatively affected the conditions of these organisms and caused high mortality during transport (Anacleto et al., 2013). Temperature significantly influenced estuarine bivalve metabolism, and the lowest temperatures were considered the best conditions during transport (Anacleto et al., 2013), consequently decreasing the excretion products and benefitting their capability to regulate oxygen consumption (Chase and McMahon, 1995; Gatenby et al., 1998). In this study, the tested temperatures i.e., $15^{\circ} \mathrm{C}$ (ten degrees lower than the reservoir water temperature) and $25^{\circ} \mathrm{C}$ (similar to the reservoir water temperature), did not affect the glycogen content of L. fortunei specimens. Based on our results, golden mussel showed tolerance to temperature fluctuation during transport, which suggests that this tolerance could strongly influence its invasiveness ability. In fact, the golden mussel can inhabit a wide range of water temperatures (Sylvester et al., 2005; Darrigran et al., 2011), and in some localities of Brazil - where the water temperature is not below $15{ }^{\circ} \mathrm{C}$ - its populations still successfully spread through new watersheds (Santos et al., 2012).

In this study, the depuration process did not significantly affect the glycogen content after $L$. fortunei specimens were transported to laboratory, as was also observed by Anacleto et al. (2013) for the bivalves Venerupis pullastra (=corrugata) (Gmelin, 1791) (Veneroida: Veneridae) and Ruditapes phillipinarum (Adams \& Reeve, 1850) (Veneroida: Veneridae). The absence of a measurable decline in glycogen content in $L$. fortunei specimens after eight hours of transport could be related to their ability to consume a small amount of glycogen through anaerobic metabolism as reported by Chen et al. (2001), in unionid bivalves after 24 hours of transport.

This work demonstrates that regardless of the depuration process and temperature conditions under which $L$. fortunei specimens are transported, this species is able to withstand environmental changes and quickly adapt (after three weeks) to the new laboratory conditions (e.g., stocking density, photoperiod, nutrition and physical-chemical conditions of the water). A recent transcriptome study identified various forms of heat shock proteins and cytochrome P450, which indicate that this mussel have a wide range of genetic repertoire that may help it overcome the stressors when it is introduced to new environments (Uliano-Silva et al., 2014). However, the same study also detected a lack of special adaptation to extremely low $\mathrm{O}_{2}$ levels. Based on this information, the use of $\mathrm{O}_{2}$ inside of plastic bags is probably critical to the survivor of the specimens during the transport process and may help to guarantee their health.

Thus, to obtain healthy $L$. fortunei specimens with good physiological conditions to perform reliable laboratory experiments, we suggest that the mussels could be captured and transported (without water/dry conditions) in plastic bags filled only with pure oxygen by using thermal insulated boxes at room temperature and acclimatized under laboratory conditions for a minimum of three weeks. This precaution should be considered for any bioassay in the laboratory to account for the health of the golden mussel specimens, thus avoiding any bias with the target organisms during the experiments and ensuring reliable results. Thus, our results show that physiological analyses could provide the most reliable and complete picture of $L$. fortunei reaction to stress and can be used to monitor the rearing and health of this species under laboratory conditions.

\section{Acknowledgements}

We thank to Dr. Adriano Pereira Paglia (UFMG) for statistical support, Dr. Domingo Rodriguez Fernandez (Itaipu Binacional) for logistical support, and especially Dra. Sandra Ludwig and Dr. Gustavo Darrigran for their valuable help in the correction of this paper. This work was supported by grants from the foundation for research from the State of Minas Gerais (Fapemig) and Vale S.A (CRA - RDP-00097-10); CNPq and CAPES.

\section{References}

ALBENTOSA, M., FERNÁNDEZ-REIRIZ, M.J., LABARTA, U. and PÉREZ-CAMACHO, A., 2007. Response of two species of clams, Ruditapes decussatus and Venerupis pullastra, to starvation: physiological and biochemical parameters. Comparative Biochemistry and Physiology B, Comparative Biochemistry, vol. 146, no. 2, pp. 241-249. http://dx.doi.org/10.1016/j.cbpb.2006.10.109. PMid:17196861

ALMEIDA, E.A., BAINY, A.C.D., LOUREIRO, A.P.M., MARTINEZ, G.R., MIYAMOTO, S., ONUKI, J., BARBOSA, L.F., GARCIA, C.C.M., PRADO, F.M., RONSEIN, G.E., SIGOLO, C.A., BROCHINI, C.B., MARTINS, A.M.G., MEDEIROS, M.H.G. and DI MASCIO, P., 2007. Oxidative stress in Perna perna and other bivalves as indicators of environmental stress in the Brazilian marine environment: antioxidants, lipid peroxidation and DNA damage. Comparative Biochemistry and Physiology Part A, vol. 146, no. 4, pp. 588-600.

ANACleto, P., MAULVAULT, A.L., BARRENTO, S., MENDES, R., NUNES, M.L., ROSA, R. and MARQUES, A., 2013. Physiological responses to depuration and transport of native and exotic clams at different temperatures. Aquaculture (Amsterdam, Netherlands), vol. 408-409, pp. 136-146. http:// dx.doi.org/10.1016/j.aquaculture.2013.05.035. 
BRASIL. Ministério do Desenvolvimento Urbano e Meio Ambiente. Secretaria Especial do Meio Ambiente, 1988. Manual de testes para avaliação da ecotoxicidade de agentes químicos. Brasília: SEMA/MHU. $351 \mathrm{p}$.

CALAZANS, S.H.C., AMERICO, J.A., FERNANDES, F.C., ALDRIDGE, D. and REBELO, M.F., 2013. Assessment of toxicity of dissolved and microencapsulated biocides for control of the Golden Mussel Limnoperna fortunei. Marine Environmental Research, vol. 91, pp. 104-108. http://dx.doi.org/10.1016/j. marenvres.2013.02.012. PMid:23582773.

CATAldo, D., BOLTOVSKOY, D. and POSE, M., 2003. Toxicity of chlorine and three nonoxidizing molluscicides to the pest mussel Limnoperna fortunei (Bivalvia:Mytilidae). Journal American Water Works Association, vol. 95, no. 1, pp. 66-78.

CHASE, R. and MCMAHON, R.F., 1995. Effects of starvation at different temperatures ondry tissue and dry shell weights in the zebra mussel, Dreissena polymorpha (Pallas). Vicksburg: U.S. Army Engineer Waterways Experiment Station. Technical Report, EL-95-4.

CHEN, L.Y., HEATH, A.G. and NEVES, R., 2001. An evaluation of air and water transport of freshwater mussels (Bivalvia: Unionidae). American Malacological Bulletin, vol. 16, pp. 147-154.

DARRIGRAN, G. and DAMBORENEA, C., 2011. Ecosystem engineering impact of Limnoperna fortunei in South America. Zoological Science, vol. 28, no. 1, pp. 1-7. http://dx.doi.org/10.2108/ zsj.28.1. PMid:21186940.

DARRIGRAN, G., DAMBORENEA, C., DRAGO, E., DRAGO, I.E. and PAIRA, A., 2011. Environmental factors restrict the invasion process of Limnoperna fortunei (Mytilidae) in the Neotropical Region: a case study from the Andean tributaries. Annales de Limnologie - International Journal of Limnology, vol. 47, no. 3, pp. 221-229. http://dx.doi.org/10.1051/limn/2011025.

DI FIORI, E., PIZARRO, H., SANTOS, A.M. and CATALDO, D., 2012. Impact of the invasive mussel Limnoperna fortunei on glyphosate concentration in water. Ecotoxicology and Environmental Safety, vol. 81, pp. 106-113. http://dx.doi. org/10.1016/j.ecoenv.2012.04.024. PMid:22595085.

DRIDI, S., SALAH ROMDHANE, M. and ELCAFSI, M., 2007. Seasonal variation in weight and biochemical composition of the Pacific oyster, Crassostrea gigas in relation to the gametogenic cycle and environmental conditions of the Bizert lagoon, Tunisia. Aquaculture (Amsterdam, Netherlands), vol. 263, no. 1-4, pp. 238-248. http://dx.doi.org/10.1016/j. aquaculture.2006.10.028.

ENGLUND, V.P.M. and PYNNONEN, K., 1996. The effect of transfer and laboratory acclimation on the acid-base and electrolyte status of the freshwater unionid mussel Anodonta anatina (L.). Journal of Molluscan Studies, vol. 62, no. 2, pp. 225-234. http:// dx.doi.org/10.1093/mollus/62.2.225.

GATENBY, C.M., MORRISON, P.A., NEVES, R.J. and PARKER, B.C., 1998. A protocol for the salvage and quarantine of Unionid mussels from zebra mussel-infested waters. In: Proceedings of the Conservation, Captive Care, and Propagation of Freshwater Mussel Symposium, 1998, Columbus. Ohio: Ohio Biological Survey, pp. 9-18.

HUMMEL, H.L., WOLF, W., ZURBERG, L., APON, R.H., BOGGARDS, M. and RUTTENBERG, V., 1989. The Glycogen contents in stressed marine bivalves: the initial absence of decrease. Comparative Biochemistry and Physiology, B, vol. 94, pp. 729-733.
KANG, C.K., PARK, M.S., LEE, P.Y., CHOI, W.J. and LEE, W.C., 2000. Seasonal variations in condition, reproductive activity, and biochemical composition of the Pacific oyster, Crassostrea gigas (Thunberg), in suspended culture in two coastal bays of Korea. Journal of Shellfish Research, vol. 19, pp. 771-778.

LEE, R., LOVATELLI, A. and ABABOUCH, L., 2008. Bivalve depuration: fundamental and practical aspects. Rome: FAO. 161 p. FAO Fisheries Technical Paper, no. 511.

MANSUR, M.C., SANTOS, C.P., PEREIRA, D., PAZ, I.C., ZURITA, M.L., RODRIGUEZ, M.T., NEHRKE, M.V. and BERGONCI, P.E.A., 2012. Moluscos límnicos invasores no Brasil: biologia, preservação e controle. Porto Alegre: Redes Editora. 412 p.

MAROÑAS, M.E. and DAMBORENEA, C., 2009. Efeito de biocidas e tolerância à exposição ao ar. In: G. DARRIGRAN and C. DAMBORENEA, eds. Introdução a Biologia das invasões. $O$ Mexilhão Dourado na América do Sul: biologia, dispersão, impacto, prevenção e controle. São Carlos: Cubo Editora, pp. 169-183.

MONTALTO, L. and DRAGO, I.E., 2003. Tolerance to desiccation of an invasive mussel, Limnoperna fortunei (Dunker, 1857) (Bivalvia, Mytilidae), under experimental conditions. Hydrobiologia, vol. 498, no. 1/3, pp. 161-167. http://dx.doi.org/10.1023/A:1026222414881.

MONTRESOR, L.C., MIRANDA-FILHO, K.C., PAGLIA, A., LUZ, D.M.R., ARAÚJO, J.M., SILVA, M.J.S., GERHARD, L., MARTINEZ, C.B.E. and VIDIGAL, T.H.D.A., 2013. Shortterm toxicity of ammonia, sodium Hydroxide and a commercial biocide to golden mussel Limnoperna fortunei (Dunker, 1857). Ecotoxicology and Environmental Safety, vol. 92, pp. 150-154. http://dx.doi.org/10.1016/j.ecoenv.2013.03.016. PMid:23582994.

NANDURKAR, H.P. and ZAMBARE, S.P., 2012. Study of acute and chronic treatment of tetracyclineon total lipid contents in various tissues of freshwater mussels, Lamellidens corrianus (Lea) \& Parreysia cylindrica (Annandale \& Prashad). Asian Journal of Biological and Life Sciences, vol. 1, no. 1, pp. 41-44.

NEWTON, T.J., MONROE, E.M., KENYON, R., GUTREUTER, S., WELKE, K.I. and THIEL, P.A., 2001. Evaluation of relocation of unionid mussels into artificial ponds. Journal of the North American Benthological Society, vol. 20, no. 3, pp. 468-485. http://dx.doi.org/10.2307/1468042.

OLIVEIRA, M.D., HAMILTON, S.K. and JACOBI, C.M., 2010a. Forecasting the expansion of the invasive golden mussel Limnoperna fortunei in Brazilian and North American rivers based on its occurrence in the Paraguay River and Pantanal wetland of Brazil. Aquatic Invasions, vol. 5, no. 1, pp. 59-73. http://dx.doi. org/10.3391/ai.2010.5.1.8.

OLIVEIRA, M.D., HAMILTON, S.K., CALHEIROS, D.F. and JACOBI, C.M., 2010b. Oxygen depletion events control the invasive golden mussel (Limnoperna fortunei) in a tropical floodplain. Wetland, vol. 30, no. 4, pp. 705-716. http://dx.doi. org/10.1007/s13157-010-0081-3.

PATRICK, S., FAURY, N. and GOULLETQUER, P., 2006. Seasonal changes in carbohydrate metabolism and its relationship with summer mortality of Pacific oyster Crassostrea gigas (Thunberg) in Marennes-Oleron bay (France). Aquaculture (Amsterdam, Netherlands), vol. 252, no. 2-4, pp. 328-338. http:// dx.doi.org/10.1016/j.aquaculture.2005.07.008.

PATTERSON, M.A., PARKER, B.C. and NEVES, R.J., 1999. Glycogen concentration in the mantle tissue of freshwater mussels (Bivalvia: Unionidae) during starvation and controlled feeding. American Malacological Bulletin, vol. 15, no. 1, pp. 47-50. 
PEKKARINEN, M. and SUORANTA, R., 1995. Effects of transportation stress and recovery and sample treatment on $\mathrm{Ca} 2+$ and glucose concentrations in body fluids of Anodonta anatina (Linnaeus). Journal of Shellfish Research, vol. 14, no. 2, pp. 425-433.

PEREYRA, P.J., ROSSINI, G.B. and DARRIGRAN, G., 2011. Toxicity of three commercial tannins to the nuisanve invasive species Limnoperna fortunei (Dunker, 1857): implications for control. Fresenius Environmental Bulletin, vol. 20, no. 6, pp. 1432-1437.

PEREYRA, P.J., ROSSINI, G.B. and DARRIGRAN, G., 2012. Toxicity oj Neem's oil, a potential biocide against the invasive mussel Limnoperna fortunei (Dunker 1857). Anais da Academia Brasileira de Ciencias, vol. 84, no. 4, pp. 1065-1071. http:// dx.doi.org/10.1590/S0001-37652012005000059. PMid:22990602.

PESTANA, D., OSTRENSKY, A., BOEGER, W.A. and PIE, M.R., 2009. The effect of temperature and body size on filtration rates of Limnoperna fortunei (Bivalvia, Mytilidae) under laboratory conditions. Brazilian Archives of Biology and Technology, vol. 52, no. 1, pp. 135-144. http://dx.doi.org/10.1590/S151689132009000100018 .

PINHEIRO, J. and GOMES, E.M., 1994. A method for glycogen determination in molluscs. Arquivos de Biologia e Tecnologia, vol. 37 , pp. 569-576.

RESGALLA JUNIOR, C., WEBER, L.I. and CONCEIÇÃO, M.B., 2008. O mexilhão Perna perna (L.). Rio de Janeiro: Editora Interciência. $324 \mathrm{p}$.

RICHARDS, G.P., 1988. Microbial purification of shellfish: a review of depuration and relaying. Journal of Food Protection, vol. 51 , no. 3 , pp. $218-251$.

ROLLA, M.E. and MOTA, H.R., 2010. Response of a major Brazilian utility to the golden mussel invasion. In: G.L. MACKIE and R. CLAUDI (eds.). Monitoring and control of macrofouling mollusks in freshwater systems. 2nd ed. Boca Raton: CRC Press, pp. 396-403.

SANTOS, S.B., THIENGO, S.C., FERNANDEZ, M.A., MIYAHIRA, I.C., GONÇALVES, I.C.B., XIMENES, R.F., MANSUR, M.C.D. and PEREIRA, D., 2012. Espécies de moluscos límnicos invasores no Brasil. In: M.C. MANSUR, C.P. SANTOS, D. PEREIRA, I.C. PAZ, M.L. ZURITA, M.T. RODRIGUEZ, M.V. NEHRKE and P.E.A. BERGONCI, eds. Moluscos límnicos invasores no Brasil: biologia, preservação e controle. Porto Alegre: Redes Editora, pp. 25-49.
STATSOFT INC., 2007 [viewed 30 September 2015]. Statistica: data analysis software system. Version 8.0 [online]. Tulsa: StatSoft Inc. Available from: www.statsoft.com

SUMNER, J.B., 1944. A method for the colorimetric determination of phosphorus. Science, vol. 100, no. 2601, pp. 413-414. http:// dx.doi.org/10.1126/science.100.2601.413. PMid:17799462.

SYLVESTER, F., CATALDO, D.H., NOTARO, C. and BOLTOVSKOY, D., 2013. Fluctuating salinity improves survival of the invasive freshwater Golden mussel at hight salinity: implications for the introduction of aquatic species through estuarine ports. Biological Invasions, vol. 15, no. 6, pp. 1355-1366. http://dx.doi.org/10.1007/ s10530-012-0373-z.

SYLVESTER, F., DORADO, J., BOLTOVSKOY, D., JUAREZ, A. and CATALDO, D., 2005. Filtration rates of the invasive pest bivalve Limnoperna fortunei as a function of size and temperature. Hydrobiologia, vol. 534, pp. 71-80. http://dx.doi.org/10.1007/ s10750-004-1322-3.

THOMPSON, R.J., BAYNE, C.J., MOORE, M.N. and CAREFOOT, T.H., 1978. Haemolymph volume, changes in the biochemical composition of the blood, and cytological responses of the digestive cells of Mytilus californianus Conrad, induced by nutritional, thermal and exposure stress. Journal of Comparative Physiology. B, Biochemical, Systemic, and Environmental Physiology, vol. 127, no. 4, pp. 287-298. http://dx.doi.org/10.1007/BF00738412.

ULIANO-SILVA, M., AMERICO, J.A., BRINDEIRO, R., DONDERO, F., PROSDOCIMI, F. and REBELO, M.F., 2014. Gene Discovery through Transcriptome Sequencing for the Invasive Mussel Limnoperna fortunei. PLoS One, vol. 9, no. 7, pp. 1-9. http://dx.doi.org/10.1371/journal.pone.0102973. PMid:25047650.

WIDDOWS, J. and BAYNE, B.L., 1971. Temperature acclimation of Mytilus edulis with reference to its energy budget. Journal of the Marine Biological Association of the United Kingdom, vol. 51, no. 04, pp. 827-843. http://dx.doi.org/10.1017/S0025315400018002.

YUSUFZAI, S.I., SINGH, H. and SHIRDHANKAR, M.M., 2010. An evaluation of different methods for transportation of the freshwater mussel Lamellidens corrianus (Lea 1834). Aquaculture International, vol. 18, no. 4, pp. 679-692. http:// dx.doi.org/10.1007/s10499-009-9290-2.

ZAR, J.H., 2009. Biostatistical analysis. 5th ed. New Jersey: Prentice-Hall. 


\section{Brazilian Journal of Biology}

\section{Erratum}

Erratum In the article "Physiological response of invasive mussel Limnoperna fortunei (Dunker, 1857) (Bivalvia: Mytilidae) submitted to transport and experimental conditions", DOI https://doi.org/10.1590/1519-6984.15315, published in Brazilian Journal of Biology, vol. 77, no. 1, p. 195, in the results of the article:

Where it reads:

The glycogen content after the first week of maintenance of $L$. fortunei specimens under laboratory conditions was significantly higher $(0.34 \pm 0.79 \mathrm{mg}$ glucose $/ \mathrm{g}$ tissue $)$ than in depurated and non-depurated field animals $(0.15 \pm 0.07 \mathrm{mg}$ of glucose / $\mathrm{g}$ of tissue) and those that were maintained for four weeks in the laboratory ( $0.09 \pm 0.06 \mathrm{mg}$ glucose / g tissue). Based on our results, there was significant difference among treatments of non-depurated animals (ANOVA: $\mathrm{F}_{5,35}=3.69$, $\mathrm{p}=0.008$ ) (Figure 2, Table 1). However, the glycogen concentrations among non-depurated animals decreased after the first week, and in the fourth week, reached concentrations at levels similar to those obtained in animals from the field $(0.42 \pm 0.11 \mathrm{mg}$ glucose $/ \mathrm{g}$ tissue $)$.

\section{It should be read:}

The glycogen content after the first week of maintenance of $L$. fortunei specimens under laboratory conditions was significantly higher $(0.79 \pm 0.34 \mathrm{mg}$ glucose $/ \mathrm{g}$ tissue $)$ than in depurated and non-depurated field animals $(0.15 \pm 0.07 \mathrm{mg}$ of glucose / $\mathrm{g}$ of tissue) and those that were maintained for four weeks in the laboratory $(0.09 \pm 0.06 \mathrm{mg}$ glucose / $\mathrm{g}$ tissue $)$. Based on our results, there was significant difference among treatments of non-depurated animals $\left(\right.$ ANOVA: $F_{5,35}=3.69$, $\mathrm{p}=0.008$ ) (Figure 2, Table 1). However, the glycogen concentrations among non-depurated animals decreased after the first week, and in the fourth week, reached concentrations at levels similar to those obtained in animals from the field $(0.09 \pm 0.06 \mathrm{mg}$ glucose $/ \mathrm{g}$ tissue $)$. 